\title{
PENGARUH KANDUNGAN DETERJEN PADA LIMBAH RUMAH TANGGA TERHADAP KELANGSUNGAN HIDUP UDANG GALAH (MACROBRACIUM ROSENBERGII)
}

\author{
Leni Handayani \\ Jurusan Budidaya Perairan Universitas Darwan Ali Kampus Kuala Pembuang \\ J1. Kihajar Dewantara, Kuala Pembuang Kabupaten Seruyan, Pos 74212 \\ E-mail : leni.handayani@unda.ac.id
}

\begin{abstract}
ABSTRAK
Penelitian ini bertujuan untuk mengatuhui pengaruh limbah rumah tangga terhadap kelangsungan hidup udang galah (Macrobracium rosenbergii). Penelitian ini menggunakan 5 perlakuan dengan 3 ulangan. Perlakuan yang digunakan adalah perlakuan A (0\%), perlakuan B (1\%), perlakuan C (3\%), perlakuan D (5\%) dan perlakuan E (7\%). Udang sampel yang digunakan dalam penelitian ini berjumlah 75 ekor. Penelitian ini dilaksanakan pada bulan April 2017. Parameter yang diamati dalam penelitian ini adalah kelangsungan hidup, gejala klinis yang ditimbulkan akibat perlakuan tersebut dan kualitas air dianalisis secara deskriptif. Hasil penelitian menunjukan bahwa limbah rumah tangga dalam hal ini adalah deterjen memberikan pengaruh yang sangat nyata terhadap kelangsungan hidup udang galah (Macrobracium rosenbergii). Semakin tinggi konsentrasi deterjen maka semakin cepat respon udang sehingga dapat menyebabkan kematian. Adanya pengaruh ini diduga karena terjadinya terjadinya perubahan kualitas air selama masa penelitian sehingga mempengaruhi sistem respirasi pada udang galah, ini dilihat dari terjadinya perubahan kualitas air yang signifikan akibat bahan tersebut. Suhu media pemeliharaan (air) mengalami peningkatan sehingga berpengaruh terhadap respirasi udang, $\mathrm{pH}$ air juga mengalami peningkatan menjadi asam.
\end{abstract}

Kata Kunci : Udang, Deterjen, Kelangsungan Hidup, Limbah, Survival Rate

\section{PENDAHULUAN}

Udang galah (Macrobracium resenbergii) merupakan salah satu komoditas yang cukup penting dalam dunia perikanan di Kabupaten Seruyan. Udang Galah (Macrobrachium rosenbergii) atau dikenal juga sebagai Giant Freshwater Prawn merupakan salah satu jenis Crustacea, yang mempunyai ukuran terbesar dibandingkan dengan udang air tawar lainnya (Suci et al. 2016) Harga jual udang galahpun relatif mahal yaitu berkisar antara $25.000-125.000$ rupiah.

Tingginya harga jual udang galah dipasaran membuat masyarakat setempat sangat memperhatikan keberadaan udang galah dilingkungan perairan. Masyarakat biasanya menangkap udang galah menggunakan pancing dan jebakan yang didesain khusus untuk menangkap udang. Seiring kemajuan daerah, hasil tangkapan nelayan mulai berkurang hal ini diduga karena banyaknya aktifitas domestik diperairan Seruyan, banyaknya aktivitas perkebunan dan bahkan pohon - pohon yang berada diperairan sudah mulai berkurang.

Berkurangnya hasil tangkapan nelayan ini membuat peneliti tertarik untuk melihat apakah aktifitas pembuangan limbah rumah tangga secara terus menerus itu dapat mempengaruhi keberadaan biota perairan terutama udang galah (Macrobracium rosenbergii). Salah satu limbah rumah tangga yang sering dibuang oleh masyarakat adalah limbah deterjen. Deterjen merupakan salah satu kebutuhan pokok bagi rumah tangga. Mencuci dengan menggunakan deterjen merupakan satu hal yang sering dilakukan oleh ibu rumah tangga. Limbah deterjen industri laundry ini akan menyebabkan turunnya kualitas bahan baku mutu perairan. Hal ini mengakibatkan terjadinya penurunan keanekaragaman biota air salah satunya kematian beberapa spesies ikan yang berada di ekosistem perairan (Yuliani, Purwanti, and Pantiwati 2015).

Pencemaran lingkungan perairan yang disebabkan oleh berbagai kegiatan masyarakat yang membuang limbah ke dalam perairan tanpa mengetahui akibat yang akan terjadi pada kualitas perairan tersebut, kegiatan rumah tangga dapat membuat pencemaran perairan sehingga mengganggu kegiatan budidaya perairan disungai, danau dan lainnya. Deterjen dengan bahanbahan aktifnya mempunyai sifat toksik dan mempunyai efek akut pada ikan, sedangkan pada konsentrasi rendah secara kronis dapat menimbulkan pengaruh terhadap organ tubuh yaitu hati dan insang.

Deterjen merupakan produk pembersih yang merupakan penyempurnaan dari sabun. Kelebihan deterjen dibandingkan sabun adalah kemampuannya dalam mengatasi air sadah dan larutan asam. Deterjen sering disebut dengan istilah deterjen sintetis yang dibuat dari bahan-bahan sintetis (Apriyani, 2017). Umumnya deterjen tersusun atas tiga komponen yaitu, surfaktan (sebagai bahan dasar deterjen) sebesar 20-30\%, builders (senyawa fosfat) sebesar 70-80 \%, dan bahan aditif 
(pemutih dan pewangi) yang relative sedikit yaitu 2-8\%. Surface Active Agent (surfaktan) pada deterjen digunakan untuk proses pembasahan dan pengikat kotoran, sehingga sifat dari deterjen dapat berbeda tergantung jenis surfaktannya (Yuliani, dkk, 2015). Deterjen adalah racun yang kuat untuk biota akuatik dan mencemari lingkungan perairan baik dari segi keperluan hidup dan kehidupan biota akuatik maupun manusia (Kamiswari, 2013)..

Berdasarkan hasil penelitian yang dilakukan oleh (maqrifah, 2015) tentang efek surfaktan terhadap pertumbuhan, kelangsungan hidup dan struktur jaringan insang benih ikan nila (Oreochromis niloticus), berpengaruh terhadap laju pertumbuhan, kelangsungan hidup, struktur jaringan insang dan efisiensi pakan ikan nila (Oreochromis niloticus). Semakin tinggi konsentrasi surfaktan maka laju pertumbuhan semakin rendah, tingkat kelangsungan hidup semakin rendah dan efisiensi pakan semakin rendah. Pada histologi insang terdapat kerusakan yang disebabkan oleh pengaruh surfaktan yaitu terjadinya hiperplasia dan hipertropi pada sel mukosa serta terjadinya hiperplasia sel dan terjadi fuse pada lamela sekunder.

Pengaruh negatif deterjen terhadap kondisi fisik dan kimia perairan yang teraliri limbah dapat terjadi secara langsung maupun tidak langsung. Beberapa pengaruh limbah deterjen terhadap lingkungan antara lain gangguan terhadap estetika oleh adanya busa putih di permukaan perairan, penurunan kadar oksigen terlarut perairan, perubahan sifat fisik dan kimia air serta terjadinya eutrofikasi. Kandungan fosfat yang tinggi dapat merangsang tumbuhnya gulma air (Yuliani, Purwanti, and Pantiwati, 2015)

Penelitian ini betujuan untuk mengetahui pengaruh limbah rumah tangga terhadap kelangsungan hidup udang galah (Macrobracium rosenbergii).

\section{RUANG LINGKUP}

Udang galah (Macrobracium rosenbergii) merupakan salah satu komoditas perikanan yang mempunyai nilai jual yang cukup tinggi. Namun beberapa tahun belakangan ini hasil tangkapan nelayan terhadap udang galah mulai berkurang. Berkurangnya hasil tangkapan ini di duga karena adanya pengaruh dari aktivitas domestik yang terjadi di perairan sungai Seruyan. Salah satu limbah rumah tangga yang sering dibuang diperairan adalah deterjen.

Pencemaran lingkungan perairan yang disebabkan oleh berbagai aktivitas masyarakat yang membuang limbah ke dalam perairan tanpa mengetahui bagaimana akibat yang terjadi pada kualitas perairan tersebut, salah satu limbah yang sering dibuang masyarakat ke perairan adalah deterjen. Limbah deterjen yang berasal dari kegiatan rumah tangga dapat membuat pencemaran perairan sehingga mengganggu kegiatan budidaya perairan disungai, danau dan lainnya. Deterjen dengan bahan-bahan aktifnya mempunyai sifat toksik dan mempunyai efek akut pada ikan, sedangkan pada konsentrasi rendah secara kronis dapat menimbulkan pengaruh terhadap organ tubuh yaitu hati dan insang

Hasil penelitian ini, diharapkan akan menjadi bahan informasi tentang pengaruh limbah rumah tangga terutama deterjen terhadap biota perairan dalam hal ini adalah udang galah (Macrobracium rosenbergii), sehingga diharapkan masyarakat akan lebih bijaksana untuk menjaga lingkungan perairan.

\section{BAHAN DAN METODE}

Berikut bahan dan metode yang digunakan dalam penelitian ini yaitu:

\subsection{Bahan Uji}

Hewan uji yang digunakan dalam penelitian ini adalah udang galah (Macrobrachium rosenbergii) dengan kepadatan 5 ekor/bak. Limbah rumah tangga yang digunakan dalam penelitian ini diambil dari air deterjen sisa limbah loundry.

\subsection{Tahapan Penelitian}

Penelitian ini dilaksanakan pada bulan april 2017. Metode yang digunakan dalam penelitian ini adalah Rancangan Acak Lengkap (RAL) dengan 5 perlakuan dan 3 kali ulangan. Perlakuan tersebut adalah:

A : pemberian deterjen dengan dosis $0 \%$

$\mathrm{B}:$ pemberian deterjen dengan dosis $1 \%$

$\mathrm{C}$ : pemberian deterjen dengan dosis $3 \%$

$\mathrm{D}$ : pemberian deterjen dengan dosis $5 \%$

E : pemberian deterjen dengan dosis $7 \%$

Prosedur pelaksanan penelitian ini adalah sebagai berikut:

\section{Persiapan Hewan Uji dan Tempat Pemeliharaan}

Hewan uji yang digunakan dalam penelitian ini adalah udang galah (Macrobracium rosenbergii) yang didapat dari para nelayan yang ada di Kuala Pembuang Kabupaten Seruyan. Media pemeliharaan yang digunakan adalah berupa akuarium yang berukuran $40 \mathrm{x}$ $30 \mathrm{x} 30 \mathrm{~cm}$. sebelum akuarium digunakan untuk penelitian terlebih dahulu dibersihkan agar media pemeliharaan yang digunakan benar - benar bersih dan siap.

Air limbah yang digunakan dalam penelitian ini adalah limbah yang diambil dari laundry disalah satu tempat usaha loundry yang ada di kuala pembuang. Kemudian limbah loundry tersebut diencerkan sesuai dosis yang ditentukan. Pengenceran dilakukan dengan pengenceran (1).

$$
\mathrm{V} 1 \times \mathrm{M} 1=\mathrm{V} 2 \times \mathrm{M} 2
$$

2. Pelaksanaan penelitian

Akuarium yang telah dipersiapkan di isi dengan air mencapai volume 20 liter, kemudian masukan udang galah sebagai hewan uji dengan kepadatan per akuarium sebanyak 5 ekor/akuarium. Selanjutnya air limbah yang 
telah disiapkan dimasukan kedalam akuarium dengan berbagai tingkatan konsentrasi pada setiap perlakuan.

\section{Parameter Pengamatan}

Pada penelitian ini yang diamati adalah respon udang galah terhadap air limbah yang telah diberikan dan gejala klinis yang diakibatkan dari air limbah tersebut serta kualitas air sebagai parameter pendukung.

\section{Parameter Uji}

Parameter yang diukur pada penelitian ini adalah kelangsungan hidup udang galah (Macrobracium rosenbergii). Kelangsungan hidup dihitung dengan menggunakan (2) (Handayani, 2019).

$$
\mathbf{S R}=\frac{\mathrm{Nt}}{\mathrm{N} 0} \mathbf{x} 100 \%
$$

Ket (2) :

SR : Derajat kelangsungan hidup (\%)

$\mathrm{Nt}$ : Jumlah ikan hidup pada akhir pemeliharaan (ekor)

No : Jumlah ikan pada awal pemeliharaan (ekor)

\section{PEMBAHASAN}

Berdasarkan hasil penelitian yang telah dilakukan, maka diperoleh data sebagai berikut:

\subsection{Kelangsungan Hidup}

Berdasarkan hasil penelitian diperoleh data kelangsungan yang tertinggi adalah pada perlakuan A yaitu $100 \%$ dan perlakuan terendah adalah perlakuan E (7\%). Rerata kelangsungan hidup udang galah selama penelitian dapat dilihat pada tabel 1 .

Tabel 1. Rerata Kelangsungan Hidup Udang Galah (Macrobrachium rosenbergii)

\begin{tabular}{|c|c|c|}
\hline No & Perlakuan & $\begin{array}{c}\text { Kelangsungan Hidup } \\
(\%)\end{array}$ \\
\hline 1 & A & 100 \\
\hline 2 & B & 80 \\
\hline 3 & C & 73.33 \\
\hline 4 & D & 66.67 \\
\hline 5 & E & 46.67 \\
\hline
\end{tabular}

Hasil uji dari penambahan limbah rumah tangga dengan tingkat konsentrasi yang berbeda pada media pemeliharaan udang menunjukkan nilai yang beragam, dimana perlakuan A sebagai kontrol adalah $100 \%$, kemudian perlakuan B $80 \%$, perlakuan C $73.33 \%$, perlakuan D $66.67 \%$ dan perlakuan E $46.67 \%$. Perbandingan rerata persentase kelangsungan hidup udang galah (Macrobrachium rosenbergii) selama penelitian pada berbagai tingkatan konsentrasi dapat dilihat pada gambar 1 .

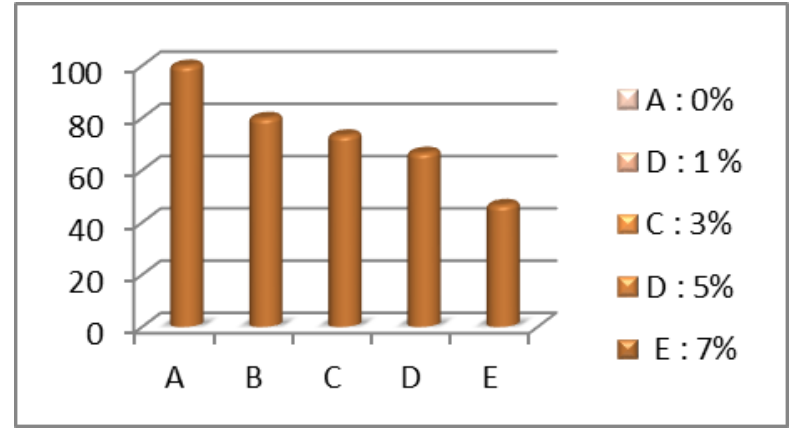

Gambar 1. Persentase Nilai SR Udang Galah

Berdasarkan gambar 1. terlihat bahwa semakin tinggi konsentrasi limbah rumah tangga dalam hal ini adalah deterjen maka semakin rendah nilai kelangsungan hidup udang galah (Macrobrachium rosenbergii). Rendahnya rerata kelangsungan hidup ini diduga karena zat toksik yang ada di dalam deterjen membuat udang galah tidak mampu mentolerirnya sehingga mempengaruhi resfirasi pada udang galah (Macrobracium rosenbergii) sehingga adanya udang galah yang mengalami kematian, hal ini sejalan dengan pendapat (Yuliani, 2015) yaitu semakin tinggi akumulasi deterjen maka semakin rendah pula suplai oksigen di dalam air, sehingga dapat menyebabkan terganggunya sistem respirasi dan dapat menimbulkan dampak yang paling buruk yaitu terjadinya kematian pada ikan. Kematian ini terjadi karena berhentinya fungsi kerja organ-organ tubuh ikan. Konsentrasi deterjen yang tinggi akan menyebabkan terjadinya peningkatan frekuensi pernafasan dua sampai tiga kali dari keadaan normal karena adanya kerusakan epithelium insang Lingkungan perairan tercemar limbah deterjen dalam konsentrasi tinggi dapat membahayakan kehidupan biota air (Maqfirah and Ezraneti R 2015).

Berdasarkan hasil analisa, data menunjukkan bahwa limbah rumah tangga dengan konsentrasi yang berbeda memberikan pengaruh sangat nyata terhadap kelangsungan hidup udang galah (Macrobrachium rosenbergii). Adanya pengaruh ini diduga karena terjadinya perubahan kualitas air selama masa penelitian sehingga mempengaruhi sistem resfirasi pada udang galah (Macrobrachium rosenbergii), ini dilihat dari terjadinya perubahan kualitas air yang signifikan akibat bahan tersebut. Suhu media pemeliharaan (air) mengalami peningkatan sehingga berpengaruh terhadap respirasi udang, $\mathrm{pH}$ air juga mengalami peningkatan menjadi asam. Kondisi perairan yang bersifat asam atau basa akan membahayakan kelangsungan hidup organisme karena dapat menyebabkan terjadinya gangguan metabolisme dan respirasi. $\mathrm{pH}$ yang tinggi menyebabkan keseimbangan antara amonium dan amoniak dalam air akan terganggu. Kenaikan $\mathrm{pH}$ di atas netral meningkatkan konsentrasi amoniak yang juga bersifat sangat toksik bagi organisme (Arizuna, Suprapto, and Muskananfola, 2014).

Perubahan pada kondisi perairan secara fluktuatif akan memberikan pengaruh kepada kondisi organisme 
yang ada di perairan tersebut. Yang menyatakan bahwa faktor lingkungan berperan sebagai pemicu terjadinya stres bagi inang (organisme perairan) akibat perubahan fisik, kimia dan biologi lingkungan sehingga daya tahan tubuh akan menurun dan menjadi rentan terhadap serangan penyakit (Khairyah and Kusdarwati, Rahayu 2012).

\subsection{Respon Udang Galah (Macrobrachium rosenbergii) dan Gejala Klinis Yang Ditimbulkan.}

Hasil pengamatan yang telah dilakukan menunjukkan respons udang yang berbeda-beda terhadap limbah rumah tangga tersebut. Pada perlakuan B,C,D dan E menunjukkan respons yang berbeda saat beberapa menit perlakuan dimasukkan ke dalam air. Perlakuan E menunjukkan respon lebih cepat dibanding perlakuan lain dimana menit ke 15 udang mulai terlihat diam dan berada didasar perairan, pergerakan udang mulai tidak beraturan dan terkadang ada yang meloncat-loncat kemudian ikan tersebut mati. sedangkan perlakuan $\mathrm{C}$ terjadi di menit ke 30 sedangkan perlakuan B dan C menunjukkan respon lebih lama dimana udang mulai terlihat diam di menit ke 55.

Respon yang ditunjukkan oleh udang galah ini diduga karena adanya pengaruh dari sifat toksit dari bahan limbah rumah tangga tersebut. Pemberian insektisida triklorofon pada media pemeliharaan dapat menyebabkan perubahan tingkah laku dimana udang akan berenang tidak beraturan, meloncat- loncat, dan akhirnya kaku atau mati. Respon ini diduga karena pengaruh sifat toksit yang menyerang sistem saraf pusat sebagai jaringan sasaran (Azizah, 2010)

Pemberian bahan limbah rumah tangga selain berdampak pada respon udang juga menimbulkan gejala klinis yang terlihat pada tubuh udang. Dimana pada perlakuan E dan D ada udang galah (Macrobracium rosenbergii). yang mengalami pendarahan dan perubahan warna pada tubuh udang. Tubuh udang berubah menjadi kemerah-merahan setelah diberikan perlakuan dengan berbagai konsentrasi, kecuali pada kontrol. Perlakuan E dan D bahkan mengalami pendarahan. Hal ini menunjukkan semakin tinggi konsentrasi yang diberikan maka akan semakin mempengaruhi kondisi udang galah. Gejala klinis yang ditunjukkan oleh udang galah (Macrobracium rosenbergii) selama penelitian ini dapat disebabkan oleh tanggapan yang terjadi pada saat zat-zat fisika atau kimia yang mengganggu proses sel atau sub sel dalam makhluk hidup sampai batas yang menyebabkan kematian secara langsung (Mayasari, 2017).

\subsection{Kualitas Air}

Parameter yang diamati dalam penelitian adalah suhu, $\mathrm{pH}$, oksigen terlarut (DO) dan amoniak $\left(\mathrm{NH}_{3}\right)$. Hasil pengukuran kualitas air selama penelitian dapat dilihat pada tabel 2 .
Tabel 2. Rerata Kualitas Akhir Sebelum dan Sesudah Penelitian Pada Media Uji .

\begin{tabular}{|c|l|c|c|c|}
\hline \multirow{2}{*}{ No } & \multirow{2}{*}{$\begin{array}{c}\text { Parameter } \\
\text { Air }\end{array}$} & \multicolumn{2}{|c|}{ Rerata Kualitas Air } & \multirow{2}{*}{ Satuan } \\
\cline { 3 - 4 } & Sebelum & Sesudah & \\
\hline 1 & Suhu & 26.5 & 29.6 & ${ }^{\circ} \mathrm{C}$ \\
\hline 2 & $\mathrm{pH}$ & 6.8 & 8.3 & \\
\hline 3 & $\begin{array}{l}\text { Oksigen } \\
\text { Terlarut } \\
(\mathrm{DO})\end{array}$ & 6.4 & 5.7 & $\mathrm{ppm}$ \\
\hline 4 & $\begin{array}{l}\text { Amoniak } \\
\left(\mathrm{NH}_{4}\right)\end{array}$ & 0 & 2.1 & $\mathrm{ppm}$ \\
\hline
\end{tabular}

Berdasarkan tabel 2. terlihat bahwa bahwa terjadi perbedaan antara sebelum dan sesudah penelitian. Dimana terlihat bahwa suhu meningkat dari 26.5 meningkat menjadi $29.6^{\circ} \mathrm{C}$ (Maqrifah, 2015) suhu air mempunyai pengaruh yang sangat besar terhadap proses pertukaran zat atau metabolisme makhluk hidup.

Peningkatan suhu yang signifikan ini berpengaruh terharap kondisi udang galah. Perubahan suhu melebihi 3 $-4^{0} \mathrm{C}$ akan menyebabkan perubahan metabolisme yang mengakibatkan kejutan suhu, meningkatkan toksisitas kontaminan yang terlarut, menurunkan DO dan dapat menyebabkan kematian (Daulae dan Syafitri ayu, 2017). Setelah diberikan bahan limbah rumah tangga, jika dilihat dari nilainya suhu berkisar antara $26.5-28.6^{\circ} \mathrm{C}$, jika dilihat dari suhu optimum untuk pemeliharaan udang galah adalah $26-29^{\circ} \mathrm{C}$, tetapi pada media pemeliharaan ini terjadi fluktuasi suhu sehingga mempengaruhi kondisi udang galah. Suhu merupakan salah satu faktor yang sangat penting dalam mengatur proses kehidupan dan penyerapan organisme. Suhu air normal adalah suhu air yang memungkinkan makhluk hidup dapat melakukan metabolisme dan berkembang biak. Suhu merupakan faktor penting di air. Suhu pada media pemeliharaan mengalami peningkatan yang signifikan sehingga terjadi fluktuasi suhu pada media. Suhu merupakan salah satu faktor eksternal yang mempengaruhi produktifitas dan aktivitas seperti pernafasan, pertumbuhan dan selera makan (Lusianti, 2013).

Kenaikan suhu ini juga berpengaruh terhadap penurunan DO pada media perairan. DO disuatu perairan sangat berperan dalam proses penyerapan makanan oleh makhluk hidup dalam air. Kandungan oksigen terlarut di dalam air merupakan salah satu penentu karakteristik kualitas air yang terpenting dalam kehidupan organisme akuatik. Sumber utama oksigen dalam suatu perairan berasal sari suatu proses difusi dari udara bebas dan hasil fotosintesis organisme yang hidup dalam perairan. Kecepatan difusi oksigen dari udara, dipengaruhi oleh beberapa faktor, seperti kekeruhan air, suhu, salinitas, pergerakan massa air dan udara seperti arus, gelombang dan pasang surut. Oksigen dimanfaatkan oleh organisme perairan untuk proses respirasi dan menguraikan zat organik menjadi zat anorganik oleh mikroorganisme. Oksigen terlarut dalam perairan dalam air berasal dari difusi udara dan hasil fotosintesis organisme berklorofil yang hidup dalam suatu perairan dan dibutuhkan oleh 
organisme untuk mengoksidasi zat hara yang masuk kedalam tubuhnya (Syahfitri, 2017)

Nilai DO menurun dari 6.4 menjadi $5.7 \mathrm{ppm}$. Penurunan nilai DO ini diduga karena pengaruh dari bahan limbah rumah tangga tersebut. Menurut (Yuliani, 2015) deterjen yang meningkat akan berdampak negatif terhadap akumulasi surfaktan pada badan-badan perairan., sehingga menimbulkan masalah pendangkalan perairan, terhambatnya transfer oksigen, dan lain-lain. Kemudian fosfat dari deterjen yang tinggi disungai, juga dapat merangsang tumbuhnya gulma air. Peningkatan jumlah tanaman air akan menyebabkan peningkatan penguraian fosfat, dan penghambatan pertukaran oksigen dalam air, sehingga kadar oksigen terlarut dalam air sangat rendah (mikroaerofil).

$\mathrm{pH}$ air selama penelitian juga meningkat dari 6.8 menjadi 8.3. perubahan $\mathrm{pH}$ ini menunjukan kondisi media pemeliharaan menjadi asam. Peningkatan $\mathrm{pH}$ yang tinggi akan menyebabkan keseimbangan antara ammonium dan ammonia dalam air akan terganggu, dimana kenaikan pH netral akan meningkatkan konsentrasi amoniak yang juga akan menjadi toksik bagi organisme. Konsentrasi ammonia yang tinggi akan berdampak terhadap menurunnya pengambilan oksigen yang disebabkan rusaknya insang, gangguan osmoregulasi dan kerusakan fisiologis jaringan (Dauhan, R. E. S., \& Efendi, E. 2014).

Perubahan nilai $\mathrm{pH}$ air juga berpengaruh terhadap nilai amoniak dimana nilai amoniak meningkat menjadi 2.1 ppm. Jika dilihat dari nilai amoniak media pemeliharaan ini sangat tinggi. Konsentrasi amoniak yang tinggi di dalam air akan mempengaruhi permeabilitas ikan oleh air dang mengurangi konsentrasi ion di dalam tubuh. Amoniak juga dapat meningkatkan konsumsi oksigen di jaringan, merusak insang dan mengurangi kemampuan darah dalam mengangkut oksigen (Ernawati, 2014).

Amonia merupakan senyawa beracun bagi udang dan hewan air lainnya. Senyawa tersebut dihasilkan bakteri dan cendawan (jamur) pada proses perombakan bahan organik, baik dalam kondisi aerob (ada oksigen) maupun anaerob (tanpa oksigen). Amoniak adalah produk akhir yang besar dari penguraian protein pada ikan. Ikan akan menguraikan protein yang ada di dalam pakan dan menyekresikan lewat insang dan kotorannya. Banyaknya amonia yang di sekresikan oleh ikan tergantung pada input pakan yang diberikan di dalam sistem budidayanya, penambahannya seperti penambahan feeding rate Amoniak dapat menyebabkan kematian pada konsentrasi $>0.8$ ppm (Ernawati, 2014).

\section{KESIMPULAN}

Limbah rumah tangga dengan konsentrasi yang berbeda dalam hal ini adalah deterjen berpengaruh sangat nyata terhadap kelangsungan hidup udang galah (Macrobrachium rosenbergii). Semakin tinggi konsentrasi deterjen maka semakin cepat respon udang dan bahkan dapat menyebabkan kematian. Nilai survival rate selama penelitian menunjuknan bahwa perlakuan A sebagai kontrol adalah $100 \%$, kemudian perlakuan B $80 \%$, perlakuan C $73.33 \%$, perlakuan D $66.67 \%$ dan perlakuan E $46.67 \%$. Selain kelangsungan hidup, penggunaan deterjen yang berlebih akan menyebabkan kandungan surfaktan yang ada dalam deterjen tersebut akan meningkat sehingga akan memberikan pengaruh kepada kualitas perairan yang dapat berdampak pada organisme yang ada diperairan.

\section{SARAN}

Adanya penelitian lanjutan tentang pengaruh deterjen misalnya dengan jenis deterjen yang berbeda dan dengan jenis ikan yang berbeda, sehingga nantinya dapat diperoleh data terbaru bagaimana dampak penggunaan limbah rumah tangga jika dibuang sembarangan dan nantinya dapat dijadikan informasi tentang bagaimana pengaruh deterjen terhadap kelangsungan udang galah ataupun organisme perairan yang lain.

\section{DAFTAR PUSTAKA}

Apriyani, N. 2017. Penurunan Kadar Surfaktan Dan Sulfat Dalam Limbah Laundry. 2: 37-44.

Arizuna, M., Suprapto, D., \& Muskanonfola, M. R.. 2014. Kandungan Nitrat Dan Fosfat Dalam Air Pori Sedimen Di Sungai Dan Muara Sungai Wedung Demak. 3: 7-13.

Azizah S, N. 2010. Ketahanan Tiha Strain Udang Dalah (Macrobrachium Rosenbergii) Terhadap Surfaktan Detetgen Alkylsulfate.

Dauhan, R. E. S., \& Efendi, E. (2014). Efektifitas Sistem Akuaponik dalam Mereduksi Konsentrasi Amonia pada Sistem Budidaya Ikan. e-Jurnal Rekayasa dan Teknologi Budidaya Perairan, 3(1), 297-302.

Handayani. L. 2019. Penggunaan Eksytak Akar Jeruju Untuk Meningkatkan Laju Pertumbuhandan Survival Rate Pada Ikan Patin Djambal (Pangasius Djambal). Sebatik 23: 153-57.

Kamiswari, R. 2013. Pengaruh Pemberian Deterjen terhadap Mortalitas Ikan Platy sp. LenteraBio, 2(1), 139-142.

Khairyah, U., and kismiyati Kusdarwati, Rahayu. 2012. Identifikasi Dan Prevalensi Jamur Pada Ikan Gurami (Osphoronemus Gouramy) Di Desa Ngrajek, Kecamatan Mungkid, Kabupaten Magelang, Jawa Tengah. Journal Of acuaculture and Fish Health 1 No. 2.

Lusianti, F. 2013. Efektifitas Penggunaan Sekam Padi, Jerami Padi dan Serabut Kayu sebagai Filter dalam Sistem Filter Undergravel pada Pemeliharaan Ikan Nila Best (Oreochromis sp.). Skripsi. Bogor: Fakultas Perikanan dan Ilmu Kelautan Institut Pertanian Bogor.

Magfirah, M., Adhar, S., \& Ezraneti, R. 2015. Efek Surfaktan Terhadap Pertumbuhan, Kelangsungan Hidup Dan Struktur Jaringan Insang Benih Ikan Nila (Oreochromis niloticus). Acta Aquatica 2: 90- 
96.

Suci, Irianti, D. S. A., Yustiati, A., \& Hamdani, H. 2016. Kelangsungan Hidup Dan Pertumbuhan Udang Galah (Macrobrachium Rosenbergii) Yang Diberi Kentang Pada Media Pemeliharaan. VII(1).

Syafitri, A. 2017. Pengaruh pemberian keong mas, cumicumi, dan cacing tanah terhadap performa kematangan gonad udang galah (macrobrachium rosenbergii) Skripsi, Fakultas Pertanian, Perikanan dan Biologi, Akuakultur, Universitas Bangka Belitung).

Yuliani, R. L. 2015. Pengaruh Limbah Deterjen Industri Laundry Terhadap Mortalitas Dan Indeks Fisiologi Ikan Nila (Oreochromis niloticus) Effect of Waste Laundry Deterjent Industry Against Mortality and Physiology Index of Nile Tilapia (Oreochromis niloticus). In Seminar Nasional XII Pendidikan Biologi FKIP UNS, , 822-28. 